\title{
神経幹切除を要した骨・軟部腫瘍の治療
}

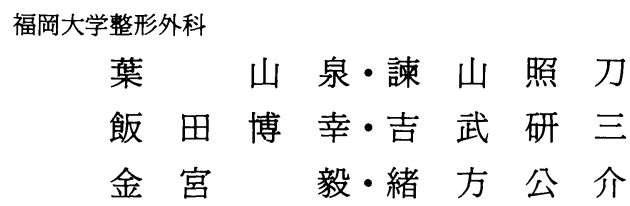

\section{Repair of Peripheral Nerve Trunk after of Resection of Bone and Soft Tissue Tumors}

by

\author{
Sansen Yoh, Teruto Isayama, Hiroyuki Iida, \\ Kenzou Yositake, Takesi Kanamiya and Kousuke Ogata \\ Department of Orthopaedic Surgery, \\ School of Medicine, Fukuoka University, Fukuoka Japan
}

\begin{abstract}
Seven patients required removal of peripheral nerve trunks due to resecion of bone and soft tissue tumors. After resection of the tumor with the diseased portion of the nerve trunk, five patients underwent immediate repair of the nerve (interposition nerve graft, the length of $8-13 \mathrm{~cm}$ ). Two patients each had malignent shwannoma and malignant fibrous histiocytoma, and one patient had a neurilemoma. Ages of the patients ranged from thirty to sixty years. Five were female. The proximal thigh and proximal lower leg was involved in two patients each and the groin in one patient each. The distal common peroneal nerve was used as the graft for repair of the proximal tibial nerve in two patients who had resection of the sciatic nerve, the distal superficial peroneal nerve was used for proximal deep peroneal nerve repair in one patient in whom the common peroneal neve was resected and the sural nerve was used for common peroneal nerve repair in one patient with resection of the common peroneal nerve. The median follow-up was 45 monrhs. Four patients $(80 \%)$ achieved a good recovery of the repaired nerve function and one patient (25\%) had minimal recovery.
\end{abstract}

Key words : Repair of Peripheral Nerve Trunk (神経移植), Bone and Soft Tissue Tumors (骨軟 部腫揚), Limb Salvage（患肢温存療法）

はじめに

骨・軟骨腫瘍の患肢温度療法では根治的な切除縁を 得るために, 主要な骨, 関節, 筋, 腱などを切除する ことは多いが，運動神経を切除する必要があることは 少ない. 主要な神経幹の切除は, 予想される機能障害 のため躊躇されることが多い ${ }^{4)}$. 神経幹切除を要した 骨・軟部腫瘍 6 例と皮虞 1 例の治療成績を検索した

ので報告する。

方法

対象症例：男 2 例，女 5 例の計 7 例。年齢は $30 \sim 60$ 才，中間値 40 才。

発生部位：骨腫瘍が上腕骨，脛骨各 1 例，軟部腫崵 が大腿 2 例, 㙰部, 下腿各 1 例, 皮膚癌が手 1 例と下 肢発生例が多かった。 
病理組織診断：骨腫瘍が軟骨肉腫, MFH, 軟部腫 瘍が神経鞘腫 (薯状型・多発例), MFH 各 1 例, 皮虐 癌が扁平上皮癌 1 例であった。

治療法：手術療法は初回手術で広範切除術として神 経幹切除を行ったのは 4 例のみで, 残りの 3 例は再発 後に神経幹切除を行った。なお，神経鞘腫（暮状型・ 多発例）の 1 例は疼痛が高度な腫瘤のみを摘出したが, 肉眼的には神経線維腫に似ていて摘出時に神経幹を切 除しなければならなかった。切除した神経幹は坐骨神 経 3 例, 総腓骨神経 2 例, 腋窩神経, 尺骨神経各 1 例 であった．また，5例に動注化学療法を併用した。

切除後の再建法として, 骨腫瘍の 2 例には連結型人 工肩関節置換, 人工䩲帯置換を各 1 例のほか, 骨腫瘍 1 例と軟部腫瘍 3 例の 4 例に神経移植を行った.うち 3 例は切除神経の末梢神経幹のうち機能廃絶予定の神 経幹（総腓骨神経, 浅腓骨神経）を採取し機能温存予 定の神経側に移植した (表 1 )。 4 例の移植神経の長 さは比較的長く $8 \sim 13 \mathrm{~cm}$ で, 神経刺激装置と顕微鏡 を使用して神経束縫合を行った。
結果

予後：観察期間 $8 \sim 132$ ヶ月（中間值 67 ヶ月）に おける予後は DOD 1 例のほか, CDF, NED, AWD 各 2 例と現在無病例は 4 例 $(57 \%)$ のみと比較的悪かっ た（表 1 ).

神経移植成績 : 4 例中 3 例は切除神経の末梢神経幹 の機能廃絶予定の神経幹側を採取し, 温存したい神経 幹側の欠損部に移植した. 即ち, 2 例は総腓骨神経を 脛骨神経に， 1 例は浅腓骨神経を深腓骨神経に移植し た. 4 例中 1 例は腓腹神経を採集し, 総腓神経に移植 した. 観察期間 8〜69 ヶ月（中間値 45 ヶ月）におけ る神経移植成績は運動回復が 3 例 (75\%)，知覚回復 が 4 例（100\%）と比較的良好であった（表 2 ）。運動 回復がみられた 3 例は術後 1 年以上経過し, 低周波刺 激により筋萎縮を予防していた例である．再建神経の 全機能が回復したのは, 脛骨神経, 総腓骨神経再建の 2 例のみであった。深腓骨神経再建の 1 例は一部のみ の回復で, 長母趾伸筋の収縮はみられたが, 前脛骨筋 にはみられなかった。

表 1 全症例の手術法と予後

\begin{tabular}{|c|c|c|c|c|c|c|c|c|c|c|}
\hline 症例 & 性 & 年令 & 発生部位 & 組織診断 & 手術法 & 切除神経 & 神経移植 & 動注療法 & 予後 & 観察期間（月） \\
\hline 1 & 男 & 41 & 上腕骨 & 軟骨肉腫 & 広切* & 腋䆚神経 & 無 & 有 & $\mathrm{CDF}$ & 132 \\
\hline 2 & 女 & 32 & 脛骨 & $\mathrm{MFH}$ & 広切** & 総腓骨神経 & 有 & 有 & NED & 29 \\
\hline 3 & 女 & 30 & 大腿 & 神経肉腫 & 摘出 $\rightarrow$ 広切*** & 坐骨神経 & 有 & 無 & NED & 78 \\
\hline 4 & 女 & 40 & 慜部 & 神経肉腫 & 摘出 $\rightarrow$ 広切*** & 坐骨神経 & 無 & 有 & DOD & 67 \\
\hline 5 & 女 & 60 & 大腿 & $\mathrm{MFH}$ & 広切 & 坐骨神経 & 有 & 有 & $\mathrm{CDF}$ & 8 \\
\hline 6 & 女 & 53 & 下腿 & 神経鞘腫 & 摘出 & 総腓骨神経 & 有 & 無 & AWD & 61 \\
\hline 7 & 男 & 34 & 手 & 扁平上皮潟 & 桖爬一広切*** & 尺骨神経 & 無 & 有 & AWD & 121 \\
\hline
\end{tabular}

$*$ 人工肩関節置換， $* *$ 人工勒帯置換， $* * *$ 再発手術時に神経切除

CDF : Continuous disease free

NED : No evidense of disease

AWD : Alive with disease

DOD : Dead of desease

表 2 神経移植例の治療成績

\begin{tabular}{c|c|c|c|c|c|c}
\hline \hline 症例 & 病理組織診断 & 切除神経 & 移植神経 & 再建神経 & 回復 & 神経移植後観察期間 (月) \\
\hline 2 & $\mathrm{MFH}$ & 総腓骨神経 & 浅腓骨神経 & 深腓骨神経 & 運動・知覚 & 29 \\
\hline 3 & 神経肉腫 & 坐骨神経 & 総腓骨神経 & 脛骨神経 & 運動・知覚 & 69 \\
\hline 5 & MFH & 坐骨神経 & 総腓骨神経 & 脛骨神経 & 知賞 & 8 \\
\hline 6 & 神経鞘腫 & 総腓骨神経 & 腓腹神経移 & 総腓骨神経 & 運動・知賞 & 61 \\
\hline
\end{tabular}




\section{症}

例

症例 $3: 30$ 才女, 左大腿神経肉腫.

1986 年 8 月腫瘤に気づく. 1987 年 4 月，坐骨神経神 経鞘腫の術前診断で初回手術は摘出術であった。しか し, 病理組織診断が神経肉腫であったので, 追加広範 切除術を勧めたが, 術後の神経脱落症状を危惧して承 諾されなかった。術後 8 ケ月で再発し, 次第に疼痛が
増強したため, 1988 年 1 月広範切除術, この時, 坐 骨神経を $13 \mathrm{~cm}$ を切除した．末梢に残存する坐骨神 経幹の総腓骨神経幹側を $13 \mathrm{~cm}$ を剝離採集して, 近 位の坐骨神経欠損部の脛骨神経幹側に移植した。再手 術後 5 年 9 ヶ月, 局所再発・肺転移なく, 筋萎縮はあ るものの脛骨神経領域の知覚は足底に知覚過敏を残し 回復，筋力も大腿二頭筋，腓腹筋，後脛骨筋の筋力は 4 と実用的な回復が見られている（図 1 ).
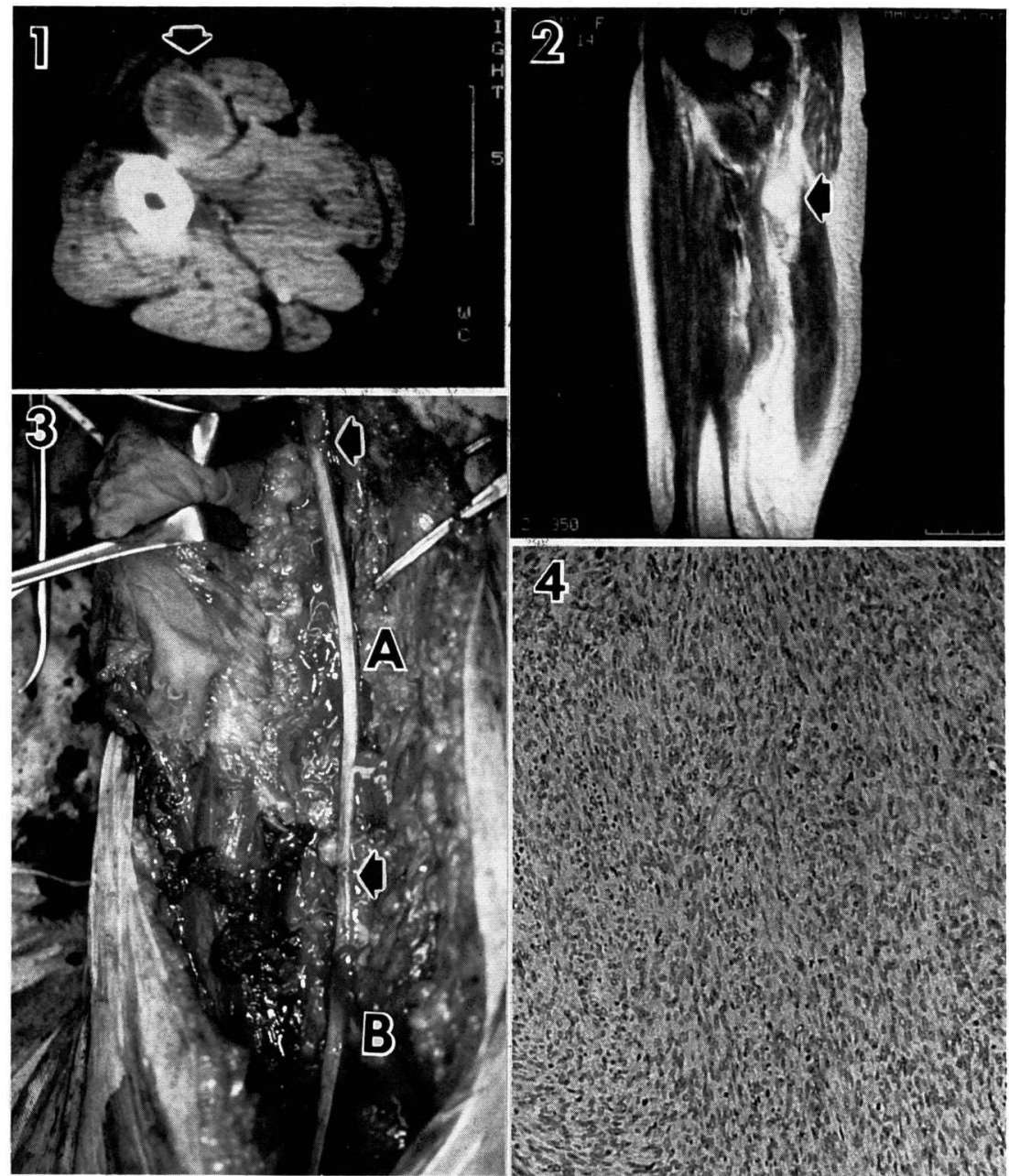

図 1 症例 330 才, 女, 左大腿神経肉腫.

（1）再発時 CT 像（が゙大腿後部坐骨神経腫崵）

（2）再発時 MRI 像（ $\rightarrow$ 大゙腿後部坐骨神経腫湟）

(3) 坐骨神経切除後の神経再建時の手術所見（十は神経吻合部，Aは末梢より採取し移植した 13 $\mathrm{cm}$ の総腓骨神経幹，B は温存した脛骨神経幹)

(4) 病理組織像 

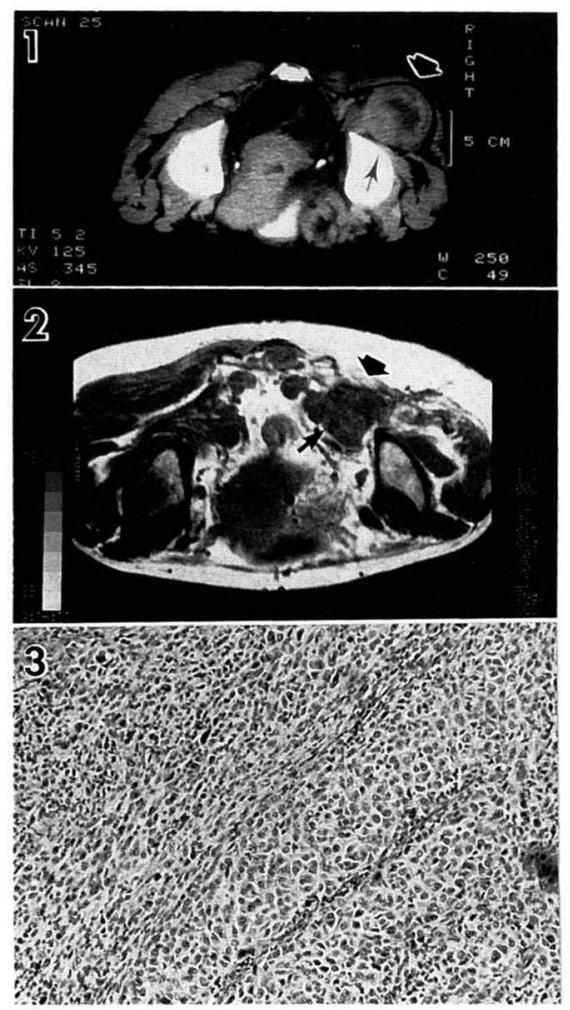

図 2 症例 440 才, 女, 右弊部神経肉腫.

（1）初回手術時の術前 CT 像（十が瞥部坐骨神 経腫瘍)

(2) 再再発時の MRI 像 ( $\rightarrow$ が後腹膜腔坐骨神経 腫場)

(3) 病理組織像

\section{症例 4：40才女, 右㯏部神経肉腫}

von Recklinghausen 病を合併. 1979 年 8 月腫瘤に気 づく. 1984 年 6 月摘出術, 3 年後局所再発. 1987 年 5 月, 薢部腫瘍広範切除術時に坐骨神経を切断した。 術後特別な再建はしなかったが, 短下肢装具と一本杖 で歩行退院した. 1988 年 5 月肺転移巣切除術. 再度 の局所再発に対し, 1988 年 9 月後腹膜腫瘍広範切除 術.この時に L5 から S3 の神経根を切断したが, 術 後の歩行能力に変化はなかった. 術後動注化学療法を 併用, 局所再発はなかったが, 肺転移のため全経過 5 年 7 ヶ月で死亡した (図 2 ).

\section{考察}

腫瘍切除時に主要な運動神経を切除し, 神経移植な どの再建をしなかった場合でも予想以上に比較的良好
な患肢機能が温存されていた。 従って, 根治的切除縁 を得るためには神経幹切除を躊躇すべきでなく, 神経 幹切除が必要であっても患肢温存療法の適応となるこ とが確認された。神経切除後の再建法として, 種々の 方法が考えられる。神経移植術について 1983 年から 1993 年迄の Med Lineによる検索では, 顔面神経再 建の報告が見られた ${ }^{12) 3)}$. 四肢の腫瘍とくに悪性腫 瘍切除時の神経再建についての報告は涉猟し得なかつ た. 我々は坐骨神経切除時に, 末梢に残存する神経幹 の機能廃絶予定の総腓骨神経幹側を採集して, 機能温 存を期待する脛骨神経幹側に移植した。このような, 切除した神経の末梢に残存する機能廃絶予定の神経幹 側を採集し, 温存したい神経幹側欠損部に移植する方 法は今までに報告がなく, 今後も利用価值が高いもの と思われる。神経再建の方法と時期は神経刺激装置 ${ }^{5)}$ と顕微鏡 ${ }^{2)}$ を使用した神経束縫合を腫湯切除時に一期 的 ${ }^{3)}$ に行う神経移植術が手技的に容易で, 回復の可能 性も高い. 運動機能回復までには 1 年以上を要するの で,この時期における低周波刺激などによる筋萎縮予 防と補装具などによる関節拘縮の予防が重要である.

\section{ま と め}

神経幹切除を要した骨・軟部腫瘍 6 例と皮膚癌 1 例 の計 7 例の治療成績を検索した。予後は DOD 1 例の ほか, CDF, NED, AWD 各 2 例であった。

3 例は切除神経の再建なしでも比較的良好な患肢機 能が温存された。 4 例に神経移植をし, 実用的な運動 回復が 3 例 $(75 \%)$, 知覚回復が $(100 \%)$ にみられた。 従って, 根治的切除縁を得るためには神経幹切除を躊 躇すべきでなく, 神経幹切除が必要であっても患肢温 存療法の適応となることが確認された.

神経幹切除の再建には切除神経の末梢に残存する機 能廃絶予定の神経幹の移植が有用であり, 神経刺激装 置 ${ }^{5)}$ と顕微鏡を使用した神経束縫合を腫瘍切除時に一 期的に行う神経移植術と筋力回復時期における筋萎縮 と関節拘縮の予防が重要である.

\section{参 考 文 献}

1) King, T. T., Sparrow, O. C., Arias, J. M. : Repair of facial nerve after removal of cerebellopontine angle tumors : a comparative study. J. Neurosurg. $78: 720-725,1993$.

2) Samii M. : Facial nerve grafting in acoustic neurinoma. Clin. Plast. Surg. 11 : 221-225, 1984. 
3) Stephanian, E., Sekhar, L. N., Janecka, L. N. et al. : Facial nerve repair by interposition nerve graft : results in 22 patients. Neurosurgery, $31: 73-77$, 1992.

4) Thomas, J. E., Piepgras, D. G., Scheithauer, B., et al. : Neurogenic tumos of the sciatic nerve. A clinicopathological study of 35 cases. Mayo Clin. Proc, 58 : 640-647, 1983.

5）葉 三泉, 高岸直人, 蒲地龍太郎ほか：整形外科にお ける末梢神経腫瘍の治療. 日整会誌, 63 :S362, 1989. 